\title{
Teaching Video NeuroImages: Upward gaze palsy is a sign of spinocerebellar ataxia type 3
}

Fábio A. Nascimento, MD, Bruno Carniatto Marques Garcia, and Helio A.G. Teive, MD

Neurology ${ }^{\circledR}$ 2018;91:e494. doi:10.1212/WNL.0000000000005913

A 32-year-old woman presented with a 5-year history of ataxia, dysphagia, and dysarthria; family history was positive for spinocerebellar ataxia type 3 (SCA3). Examination revealed bulging eyes, upward gaze palsy with vertical nystagmus, bilateral horizontal nystagmus, slow saccades, dysmetria, and gait ataxia (video). Neuroimaging showed moderate cerebellar atrophy. Neuropsychological evaluation showed deficits in memory and executive function. Based on the patient's clinical presentation and examination, SCA3 was suspected, and subsequently confirmed with genetic testing.

Upward gaze palsy appears to be a distinguishing feature of SCA3 and, therefore, may assist in the clinical differentiation of SCAs. ${ }^{1,2}$

\section{Author contributions}

F.A.N.: study concept and design, data analysis and interpretation, drafting the manuscript. B.C.M.G.: study concept and design, data analysis and interpretation, drafting the manuscript. H.A.G.T.: study concept and design, data analysis and interpretation, study supervision, revising the manuscript, final approval. All authors accept responsibility for conduct of the research.

\section{Study funding}

No targeted funding reported.

\section{Disclosure}

The authors report no disclosures relevant to the manuscript. Go to Neurology.org/ $\mathrm{N}$ for full disclosures.

\section{References}

1. Lima L, Coutinho P. Clinical criteria for diagnosis of Machado-Joseph disease: report of a non-Azorena Portuguese family. Neurology 1980;30:319-322.

2. Coutinho P. Doença de Machado-Joseph: tentativa de definição. Tese de Doutorado, Instituto de Ciências Biomédicas, Universidade do Porto, Porto, Portugal; 1992.
Correspondence

Dr. Nascimento

nascimento.fabio.a@

gmail.com

\section{MORE ONLINE}

\section{- Video}

$\rightarrow$ Teaching slides

links.lww.com/WNL/

A600

From the Department of Neurology (F.A.N.), Baylor College of Medicine, Houston, TX; and Department of Internal Medicine, Division of Neurology (B.C.M.G., H.A.G.T.), Universidade Federal do Paraná, Curitiba, Paraná, Brazil.

Go to Neurology.org/N for full disclosures. Funding information and disclosures deemed relevant by the authors, if any, are provided at the end of the article. 


\section{Neurology}

\section{Teaching Video NeuroImages: Upward gaze palsy is a sign of spinocerebellar ataxia type 3}

Fábio A. Nascimento, Bruno Carniatto Marques Garcia and Helio A.G. Teive

Neurology 2018;91;e494

DOI 10.1212/WNL.0000000000005913

This information is current as of July 30, 2018

\section{Updated Information \&} Services

\section{References}

Subspecialty Collections

Permissions \& Licensing

Reprints including high resolution figures, can be found at: http://n.neurology.org/content/91/5/e494.full

This article cites 1 articles, 1 of which you can access for free at: http://n.neurology.org/content/91/5/e494.full\#ref-list-1

This article, along with others on similar topics, appears in the following collection(s):

Gait disorders/ataxia

http://n.neurology.org/cgi/collection/gait_disorders_ataxia Spinocerebellar ataxia

http://n.neurology.org/cgi/collection/spinocerebellar_ataxia

Information about reproducing this article in parts (figures,tables) or in its entirety can be found online at:

http://www.neurology.org/about/about_the_journal\#permissions

Information about ordering reprints can be found online:

http://n.neurology.org/subscribers/advertise

Neurology ${ }^{\circledR}$ is the official journal of the American Academy of Neurology. Published continuously since 1951, it is now a weekly with 48 issues per year. Copyright (O) 2018 American Academy of Neurology. All rights reserved. Print ISSN: 0028-3878. Online ISSN: 1526-632X.

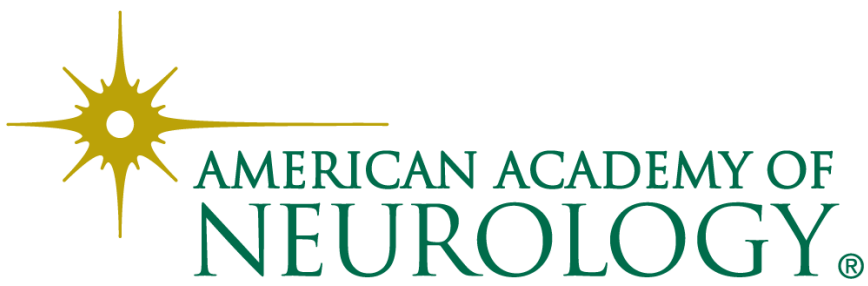

